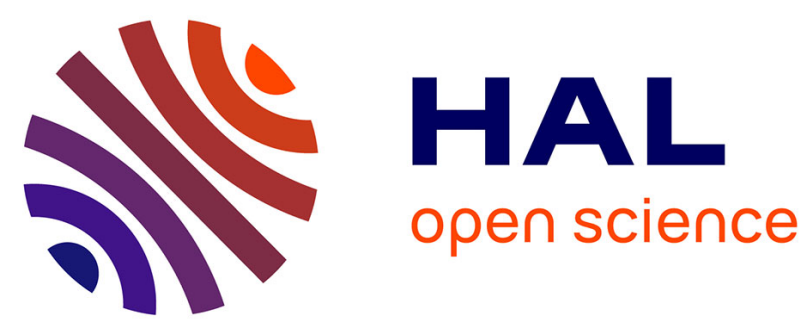

\title{
How mobile is tritiated water through unsaturated cement-based materials? New insights from two complementary approaches
}

S. Savoye, A. Rajyaguru, N. Mace, S. Lefevre, G. Spir, J.C. Robinet

\section{- To cite this version:}

S. Savoye, A. Rajyaguru, N. Mace, S. Lefevre, G. Spir, et al.. How mobile is tritiated water through unsaturated cement-based materials? New insights from two complementary approaches. Applied Radiation and Isotopes, 2017, 139, pp.98-106. 10.1016/j.apradiso.2018.04.019 . cea-02421724

HAL Id: cea-02421724

https://hal-cea.archives-ouvertes.fr/cea-02421724

Submitted on 20 Dec 2019

HAL is a multi-disciplinary open access archive for the deposit and dissemination of scientific research documents, whether they are published or not. The documents may come from teaching and research institutions in France or abroad, or from public or private research centers.
L'archive ouverte pluridisciplinaire HAL, est destinée au dépôt et à la diffusion de documents scientifiques de niveau recherche, publiés ou non, émanant des établissements d'enseignement et de recherche français ou étrangers, des laboratoires publics ou privés. 
Manuscript Number:

Title: How mobile is the tritiated water through unsaturated cement-based materials? New insights given by two innovative and complementary techniques

Article Type: Research Paper

Keywords: Tritiated water (HTO); Diffusion; Cement; Desaturation; Osmosis

Corresponding Author: Dr. Sebastien Savoye, PD Dr

Corresponding Author's Institution: CEA

First Author: Sebastien Savoye, PD Dr

Order of Authors: Sebastien Savoye, PD Dr; Ashish Rajyaguru; Nathalie Macé, Dr; Serge Lefevre; Jean-Charles Robinet, Dr

Abstract: This work presents a novel approach to study tritiated water (HTO) diffusion through unsaturated cement-based materials (hardened CEM $\mathrm{V} / \mathrm{A}$ cement pastes). The diffusion studies were performed under hydric conditions covering those that can prevail in near-surface disposal facilities for short-lived nuclear waste. In order to investigate the required large range of suction, two complementary techniques were developed. The first technique was based on a through-diffusion method where suction (up to $9 \mathrm{MPa}$ ) was controlled using osmosis process. In the second technique diffusion experiments were performed in humidity chambers controlled by under-saturated saline solutions (suction up to $170 \mathrm{MPa}$ ). Tritiated water (HTO) was added in the saline solution and diffused through the studied material in gas form. This latter method showed that the extent of irreversible HTO uptake on cement-based materials increased with desaturation. Moreover, diffusive data acquired by means of the two techniques revealed a decrease of effective diffusion coefficient by a factor of 10 from 100\% to 23\% of saturation degree. Comparison with dihydrogen (HT) diffusion results suggests that HTO diffuses through unsaturated cement-based materials at rates more than 4 orders of magnitude lower. 
Direction de l'Energie Nucléaire

Direction Déléguée aux Activités Nucléaires de Saclay

Département de Physico-Chimie

Service d'Etude du Comportement des Radionucléides

Laboratoire de Mesures et Modélisation de la Migration des Radionucléides

Saclay, the 4th of July 2017

Editor to Journal of Hazardous Materials

Attached you will find a manuscript entitled "How mobile is the tritiated water through unsaturated cementbased materials? New insights given by two innovative and complementary techniques" S. Savoye (1), A. Rajyaguru (1), N. Macé (1), S. Lefèvre (1), , G. Spir (1), J.C. Robinet (2)

(1) Den-Service d'Etude du Comportement des Radionucléides (SECR), CEA, Université ParisSaclay, F-91191 Gif-sur-Yvette, France

(2) R\&D Division, Transfert Unit, Andra, F-92298 Châtenay-Malabry, France

The contact author is Sébastien Savoye

tel.: 0033169087751.

fax.: 0033169083242

email: sebastien.savoye@cea.fr

Total word count of the manuscript

Total number of words: 5898

Total number of Tables: 2

Total number of Figures: 5

Best regards

Dr. Hab. Sébastien SAVOYE

Commissariat à l'énergie atomique

Den-Service d'Etude du Comportement des Radionucléides (SECR), CEA, Université Paris-Saclay

91191 Gif sur Yvette Cedex

Tél : (33) 0169087751 - Fax : (33) 0169083242 sebastien.savoye@cea.fr

Etablissement public à caractère industriel et commercial

R.C.S. PARIS B 775685019 


\section{${ }^{*}$ Novelty Statement (maximum limit:100 words)}

In this article, we propose two innovative and complementary methods to accurately determine the diffusive properties of tritiated water through cement-based materials under varying saturation state ( 20\% to $100 \%)$. In our knowledge, no such approach has been studied in literature. Thus, the results we present here should help the scientific community that focuses on radioactive disposal and nuclear decommissioning. In such a context cementitious waste materials could be partially water-saturated. Therefore, it is necessary to determine if tritiated water (HTO) migration is similar to that of tritiated gas (HT), known to be very fast under unsaturated conditions. 


\section{Graphical abstract:}

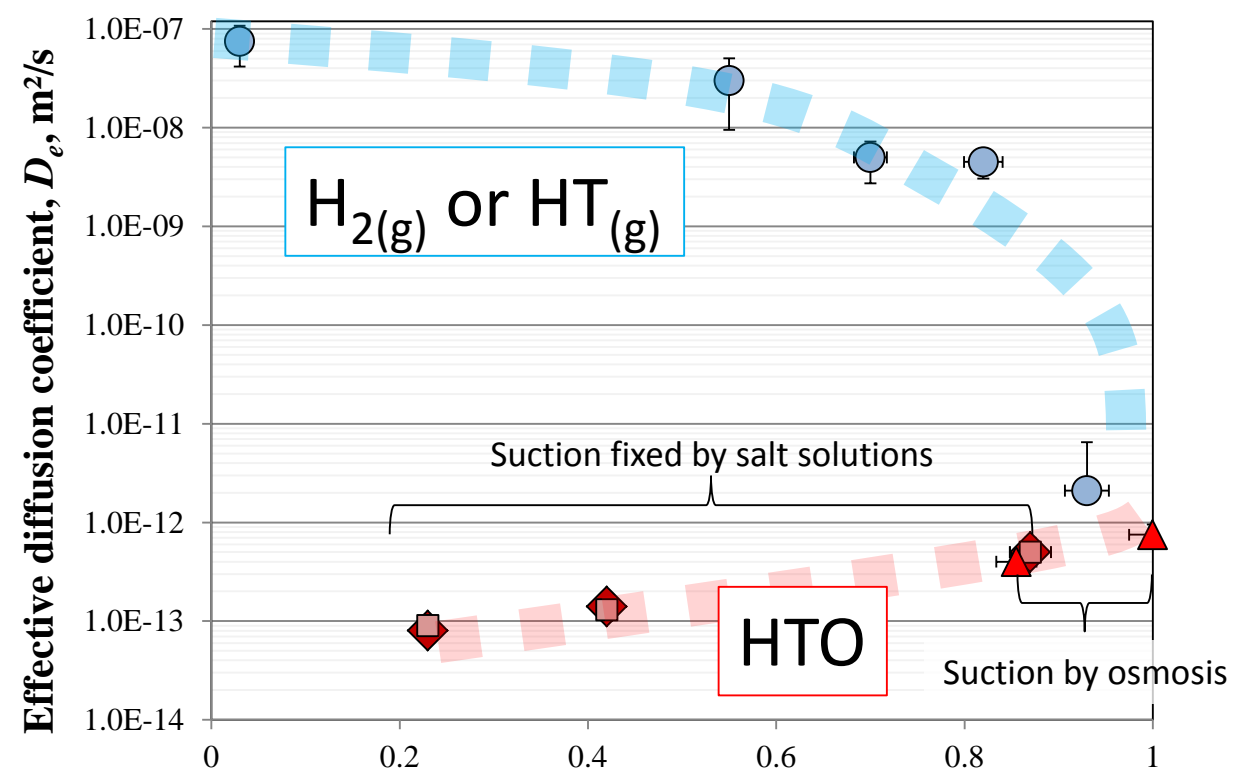

Saturation degree of hardened cement sample, - 


\title{
Keywords:
}

Tritiated water (HTO); Diffusion; Cement; Desaturation; Osmosis; Saline solution

\section{Highlights:}

- Osmosis allows HTO diffusion experiments to be performed up to $9 \mathrm{MPa}$ of suction

- Diffusive vapor exchange method enables the application of suction up to $170 \mathrm{MPa}$

- Extent of irreversible HTO uptake on cement-based materials increases with desaturation

- HTO diffuses 10000 times slower through unsaturated cement-based materials than HT

\begin{abstract}
This work presents a novel approach to study tritiated water (HTO) diffusion through unsaturated cement-based materials (hardened CEM V/A cement pastes). The diffusion studies were performed under hydric conditions covering those that can prevail in near-surface disposal facilities for shortlived nuclear waste. In order to investigate the required large range of suction, two complementary techniques were developed. The first technique was based on a through-diffusion method where suction (up to $9 \mathrm{MPa}$ ) was controlled using osmosis process. In the second technique diffusion experiments were performed in humidity chambers controlled by under-saturated saline solutions (suction up to $170 \mathrm{MPa}$ ). Tritiated water (HTO) was added in the saline solution and diffused through the studied material in gas form. This latter method showed that the extent of irreversible HTO uptake on cement-based materials increased with desaturation. Moreover, diffusive data acquired by means of the two techniques revealed a decrease of effective diffusion coefficient by a factor of 10 from $100 \%$ to $23 \%$ of saturation degree. Comparison with dihydrogen (HT) diffusion results suggests that HTO diffuses through unsaturated cement-based materials at rates more than 4 orders of magnitude lower.
\end{abstract}




\section{Introduction}

Cement-based materials are widely used in radioactive and non-radioactive, hazardous wastes [1]. In some nuclear disposal facilities, they constitute primary barriers against radionuclide or toxic species release, due to their high containment properties. Indeed, their low permeability limits the radionuclide transfer to very slow diffusive process [2]. However, there are many situations in waste disposal facilities where such materials can be partially water-saturated, leading to potential changes of radionuclide transport properties. For example, during the exploitation period of near-surface disposal facilities of short-lived nuclear waste, cement-based materials can be partially desaturated due to significant interactions with the atmosphere. Similar is the case in deep geological facility for the disposal of long-lived intermediate and high level nuclear waste. Here, the degree of saturation of cement-based materials should be controlled by the surrounding relative humidity that is imposed by ventilation of the underground drifts and shafts during the exploitation period, and by gas generation (radiolysis, anoxic corrosion...) during the post-closure period. Under these various conditions, the saturation degree of cement-based material thus could go down to a few tens \% [2].

The evaluation of the saturation effect on radionuclide migration, i.e. mainly by diffusion, in cement-based materials therefore requires investigation at large range of degree of saturation. However, determining radionuclide diffusion coefficients through cement-based material still remains a challenging work in fully-saturated conditions. Acquiring these diffusion coefficients for controlled partially saturation conditions thus constitutes a knotty task. A few studies are reported in literature on behavior of radionuclide in partially water-saturated cement-based materials. Most of diffusion testing used the over-saturated saline solution method for imposing suction, known however to be mainly adapted to suctions higher than $8.5 \mathrm{MPa}$, because below this value the relative uncertainty on the imposed suction is significant, higher than $15 \%$ [3]. Dridi and Lacour [4] studied the diffusion of lithium as $\mathrm{Li}^{+}$, through hardened cement pastes by means of the transient half-cell technique under relative humidity conditions varying from $100 \%$ to $33 \%$ imposed by saline solution. Their work showed a decrease by almost two orders of magnitude of the lithium diffusion coefficient from fullysaturated sample to the sample saturated at 0.25 . In this study, the experimental issues related to the half-cell method made data interpretation problematic. The diffusion of tritiated water (HTO) was indirectly studied by Numata et al. [5] using HTO adsorption experiments onto mortar samples nearlysaturated with water at relative humidity of $93 \%$. In this work, very rough estimations of HTO diffusion coefficient were acquired using tritium profiles within samples. Sercombes et al. [6] investigated the diffusion of gases, especially, dihydrogen, through unsaturated hardened cement pastes. Here, they found a sharp increase of dihydrogen diffusion coefficient for hardened cement pastes by more than 3 orders of magnitude when degrees of saturation were lower than 0.8 . We recently presented a new setup allowing the diffusion coefficient of tritiated water and various solutes to be quantified through natural materials (claystones and compacted clay minerals) under partiallysaturated conditions using osmotic approach [7-9]. As already mentioned by Cuisinier et al. [3], osmotic approach enables us to impose suction up to $9 \mathrm{MPa}$ associated to very low uncertainties on its estimation. It means that this method is complementary with respect to the saline solution method for investigating degrees of saturation close to full-saturation.

The aim of the present work is to investigate the diffusion of tritiated water through cement-based materials under a large suction range (0 to $170 \mathrm{MPa})$, using two innovative and complementary techniques. Both enable the study of a large range of water saturation. Motivation to focus on HTO diffusive behavior is twofold. First of all, under fully-saturated conditions, diffusion of tritiated water is classically used as a reference tracer for qualifying the containment properties of porous materials 
(claystones, cement-based materials, etc...) [10-12]. Therefore, one issue is to know how HTO diffusion coefficient evolves with saturation. Resolving this issue would thus demonstrate as whether assuming HTO as reference is still valid when dehydrating. Secondly, tritiated water can occur under both liquid and vapor forms in unsaturated cement-based materials used in several types of nuclear facilities, e.g. near-surface disposal facilities, fusion reactor or tritium handling facility [13-17]. Under these conditions, further investigations are thus necessary to determine if HTO diffusion rates are as high as gas diffusive rates [6] or as low as the ionic solutes ones [4] when dehydrating.

For this reason, the first technique allowing through-diffusion experiments to be conducted under suction values imposed by osmosis up to $9 \mathrm{MPa}$ has been adapted to cementitious conditions. These conditions are known to be more aggressive than the ones prevailing within natural materials, such as claystones [7]. The second technique based upon the vapor exchange approach has been considered to determine the diffusion behavior of HTO under higher suction values, i.e. up to $170 \mathrm{MPa}$. This technique was initially developed by Rübel et al. [18], improved by Savoye et al. [19] and Altinier et al. [20] to determine HDO content in pore-water of claystones close to the full saturation. In these studies, an initially HDO-free saline solution was equilibrated with a clayey pore-water solution via vapor exchange in a tight container. Then, the HDO content measurement in saline solution allows pore-water HDO content to be indirectly estimated. We have proposed to adapt this technique considering two main changes. Firstly, in our case, the under-saturated saline solution, initially spiked with HTO was regularly sampled for monitoring its HTO activity evolution until equilibrium via vapor exchange. This monitoring enabled us to determine the diffusive rate at which HTO penetrated into cement-based materials. Afterwards, by replacing saline solution by HTO-free solution, the diffusive rate at which HTO goes out of cement-based material was estimated. These two phases correspond to two successive in-and out-diffusion experiments. Secondly, in order to impose broader suction range to cement-based materials, the under-saturated saline solution of $\mathrm{NaCl}$ used in literature [18-20] was replaced by under-saturated solutions of $\mathrm{LiCl}$ at various concentrations, capable of imposing a larger suction range, up to $300 \mathrm{MPa}[21]$.

\section{Experimental}

\subsection{Preparation of the samples}

Cement pastes based on a CEM V/A cement (trade name CEM V/A (S-V) 42.5N PM-ES-CP1 NF "PMF3", Rombas, Calcia) were used for this study. Cement paste samples were prepared with an initial water to cement ratio of 0.4. They were poured into closed cylindrical polyethylene plastic molds $(51.5 \mathrm{~mm}$ in diameter and $53.0 \mathrm{~mm}$ in height) and initially cured at $100 \%$ relative humidity chamber for 28 days. After the curing period, some samples were submitted to a high-pressure extraction so as to collect the cement pore-water solution. This extracted pore water solution was then characterized by ionic chromatography (DIONEX DX 120 column, using $20 \mathrm{mM}$ MSA as eluent for cation measurements and DIONEX DX 600 column with $14 \mathrm{mM} \mathrm{NaOH}$ eluent for anion measurements). The other hardened cement pastes (HCP) samples were removed from the mold and kept for at least 6 months prior to be used in artificial cement pore-water solution which correspond to a $\mathrm{Ca}(\mathrm{OH})_{2}$ oversaturated solution with $(79 \pm 2) \mathrm{mmol} \mathrm{L}^{-1}$ of $\mathrm{Na}^{+},(291 \pm 2) \mathrm{mmol} \mathrm{L}^{-1}$ of $\mathrm{K}^{+},(0.57 \pm$ $0.03) \mathrm{mmol} \mathrm{L}^{-1}$ of $\mathrm{Cl}^{-}$and $(0.96 \pm 0.04) \mathrm{mmol} \mathrm{L}^{-1}$ of $\mathrm{SO}_{4}{ }^{2-}$ resulting to a $\mathrm{pH}$ value of $(13.5 \pm 0.1)$. All $\mathrm{pH}$ measurements were performed at $(22 \pm 1)^{\circ} \mathrm{C}$ using a Metrohm ${ }^{\circledR}$ glass $\mathrm{pH}$ electrode filled with $3 \mathrm{M}$ $\mathrm{KCl}$ solution and $\mathrm{pH}$ standard solutions (Merk, CERTIPUR®). 
For the through-diffusion experiments using osmosis technique, a HCP specimen was machined using a lathe to obtain a 36-mm-diameter cylinder. Seven sub-samples were then sliced using a diamond wire saw under water into 1-mm thick disks (Table 1). These disks were stored in desiccator containing a KI-oversaturated saline solution at $(22 \pm 2)^{\circ} \mathrm{C}$ (relative humidity $=69 \%$ ) under hydric equilibrium, which was achieved after $c a .3$ months (indicated by mass stabilization). This initial dehydration of the HCP samples at a level lower than those imposed by the osmotic method prevents any shrinkage phenomena (only hydration pathway). Some of these samples which were to be used for diffusion experiments were partly re-saturated using osmotic technique (Table 1). The remaining samples were dedicated for comparison of HCP saturation degree imposed by osmotic method with over-saturated saline solution method. Thus, four samples were submitted to over-saturated saline solutions with $\mathrm{K}_{2} \mathrm{SO}_{4}, \mathrm{KH}_{2} \mathrm{PO}_{4}, \mathrm{BaCl}_{2}$ and $\mathrm{KI}$ at $(22 \pm 2)^{\circ} \mathrm{C}$, causing four relative humidity ( $\mathrm{RH}$ ) values estimated to $98 \%, 95 \%, 90 \%, 69 \%$ respectively [22,23] and the last sample was partly resaturated with the osmotic technique before the determination of its degree of saturation.

For the in-and out-diffusion experiments using saline solutions, a HCP specimen was placed on a lathe to obtain a 49-mm diameter cylinder. Six sub-samples were then sliced using a diamond wire saw under water into $2.5-\mathrm{mm}$ thick piece (Table 1). These samples were stored in desiccator containing a $\mathrm{KC}_{2} \mathrm{H}_{3} \mathrm{O}_{2}$ - oversaturated saline solution at $(22 \pm 2)^{\circ} \mathrm{C}$ (relative humidity $=23 \%$ ), under hydric equilibrium, which was achieved after $c a .5$ months (indicated by mass stabilization). Half samples were dedicated to the determination of the saturation degree and the other ones for the in- and out-diffusion experiments.

All the preparation and handling were made in a $\mathrm{CO}_{2}$-free glovebox to avoid atmospheric carbonation phenomena.

\subsection{Petrophysical measurements}

In order to determine the volumetric water content and the degree of saturation as a function of imposed suctions, petrophysical measurements were performed. Volume of sample, $V_{\text {sample }}$, is determined by measuring the pressure exerted by the sample immersed in alkaline solution according to Archimedes' principle, and its dry mass, $M_{d}$, is determined by drying it at $60^{\circ} \mathrm{C}$ until mass stabilization [24]. This provides porosity, $\phi$, which is defined as the ratio between the total pore volume, $V_{p}$, and the sample volume, as:

$$
\phi=\frac{V_{p}}{V_{\text {sample }}}=\frac{M_{\text {water }}-M_{d}}{\rho_{\text {wat }} \cdot V_{\text {sample }}}
$$

Where $M_{\text {water }}$ is the total mass of sample, $\rho_{\text {wat }}$ is the density of the HCP pore-water solution, measured independently at $1.008 \mathrm{~g} \mathrm{~cm}^{-3}$ at $(22 \pm 2)^{\circ} \mathrm{C}$ using an electronical densimeter (30PX PortableLab ${ }^{\mathrm{TM}}$, Mettler Toledo).

Water saturation level, $S_{w}$, is defined as the ratio between the volume of pores filled with water, and the total pore volume, so that it is obtained at given $\mathrm{RH}$ as:

$$
S_{w}(R H)=\frac{V_{p}^{\text {water }}}{V_{\text {sample }}}=\frac{M_{\text {water }}-M_{s}(R H)}{M_{\text {water }}-M_{d}}
$$

Then, the volumetric water content, $\theta$, is calculated by: 


$$
\theta=S_{w} \text { x } \phi
$$

\subsection{Through-diffusion experiments carried out under suction fixed by osmosis}

Osmosis allows the control of water suction in the sample while maintaining contact with a chemical solution. This suction is generated by the osmosis process between the pore water (present in the pores of the sample) and a highly-concentrated solution with large-sized molecules of polyethylene glycol (PEG). The sample is separated from PEG-solution by a semi-permeable membrane (which is permeable to all except PEG). The exclusion of PEG from the sample results in a chemical-potential imbalance between the water in the sample, and the water in the reservoir chambers. This osmotic suction thus keeps the sample unsaturated. Moreover, the value of the imposed suction and resulting saturation degree of the sample depends on the PEG concentration in solution [25]. In the present study, the degrees of saturation were reached using two extreme PEG additions: 0 and $0.95 \mathrm{~g}$ of PEG per $\mathrm{g}$ of initial solution. These two PEG solutions led to suction values of 0 (i.e., saturated conditions) and $9 \mathrm{MPa}$, respectively [7]. The equivalent relative humidity at suction of $9 \mathrm{MPa}$ is equal to $93 \%$ at ambient temperature. Semi-permeable membranes with $3500 \mathrm{~g} \mathrm{~mol}^{-1}$ molecular weight cut-off (MWCO) were chosen in order to prevent the PEG 6000 (i.e. $6000 \mathrm{~g} \mathrm{~mol}^{-1}$ molecular weight) from bypassing the membranes. Note that the chemical stability of membranes and PEG 6000 under alkaline aggressive conditions were preliminary checked by means of long-term tests that lasted for more than one year.

The experimental setup used for HTO through-diffusion experiments consists of a polyvinyl chloride cell, in which a large HCP sample holder is fixed between two reservoir compartments, sealed into position by means of O-rings to avoid an eventual leakage [12]. A schematic view of this large sample holder is given in Fig. 1a. The 36-mm-diameter HCP sample was glued in a small sample holder, using an epoxy adhesive, and the resulting piece was sandwiched between two semi-permeable membranes fabricated of cellulose acetate (Spectra-Por 3500 Da, Spectrum laboratories, USA). Afterwards, polyetheretherketone (PEEK) grids (Polyetheretherketone - Mesh, Goodfellow, England) with 45 meshes were put between the O-rings to limit the dead-volume. Then, two end-pieces were placed in position. The inlet and outlet compartments of the through-diffusion cells were then filled by a synthetic solution of chemical composition closer to the HCP pore-water solution. The artificial cement pore-water (ACW) solution was prepared with ultrapure deionised water $\left(18.2 \mathrm{M} \Omega \mathrm{cm}^{-1}\right.$, MilliQ ${ }^{\circledR}$ water, Millipore), PEG 6000 (Merck, Germany), and commercial salts (American Chemical Society reagent grade or higher quality and purity salts. PEG was then added to the solution. Prior to HTO addition into the inlet compartment, a three months period was considered to ensure the complete hydric equilibrium with the HCP paste sample. This period was estimated based on classic equilibrium tests performed on HCP paste sample put in a desiccator with a relative humidity imposed by a $\mathrm{K}_{2} \mathrm{SO}_{4}$ saline solution $(\mathrm{RH} \sim 98 \%$ ) until its mass stabilization. As mentioned above, the saturation degree of the HCP sample under a suction of 9 Mpa imposed using osmotic technique was determined from a dedicated diffusion cell.

After the re-saturation step, the upstream reservoir was filled with a freshly prepared ACW solution labelled with tritiated water (at $1.8 \mathrm{MBq} \mathrm{kg}^{-1}$ of solution without PEG prepared from a HTO standard solution purchased from AREVA NP-LEA, France). The downstream reservoir was filled with a freshly prepared ACW solution without HTO tracer. During the through-diffusion experiment, the solution in the downstream reservoir was regularly replaced to maintain the lowest tracer concentration as reasonably possible, i.e. less than $3 \%$ of the one measured in the upstream reservoir. 


\subsection{In-and out-diffusion experiments with suction fixed by under-saturated saline solutions of LiCl}

A given saline solution at a definite concentration and at constant temperature is in equilibrium with a fixed partial vapor pressure of water, hence marking a fixed relative humidity [22, 26]. Unsaturated saline solutions are generally less attractive as compared to over-saturated saline solutions for humidity control, since they can gain or lose water, leading to a change of their concentration and the corresponding relative humidity. However, due to the fact that HTO activity measurement is impossible in over-saturated saline solution (heterogeneous system), the use of unsaturated saline solution is required in our case.

To reach a rough hydric equilibrium, over-saturated saline solutions with $\mathrm{KC}_{2} \mathrm{H}_{3} \mathrm{O}_{2}(\mathrm{RH} \sim 23 \%)$, $\mathrm{KI}(\mathrm{RH} \sim 69 \%)$ or $\mathrm{K}_{2} \mathrm{SO}_{4}(\mathrm{RH} \sim 98 \%)$ at $(22 \pm 2)^{\circ} \mathrm{C}$ were first used. When sample mass was stabilized, meaning no risk of water loss or gain, we used unsaturated solutions of lithium chloride at concentrations imposing relative humidity values close to the ones imposed by the three over-saturated saline solutions. Based on the study by Young [22], three solutions with $\mathrm{LiCl}$ concentrations equal to $12.8 \mathrm{~mol} \mathrm{~kg}_{\text {water }}{ }^{-1}, 5.5 \mathrm{~mol} \mathrm{~kg}_{\text {water }}{ }^{-1}$ and $1.2 \mathrm{~mol} \mathrm{~kg}_{\text {water }}{ }^{-1}$ were prepared, fixing relative humidity to $29 \%, 69 \%$ and $98 \%$, respectively. These relative humidity values were measured using humidity/temperature probes (HydroClip HC2-S, Rotronic, Switzerland). Note that for analytical reasons, $12.8 \mathrm{~mol} \mathrm{~kg}_{\text {water }}{ }^{-1}$ was the maximum concentration allowed to measuring HTO activity with a good accuracy (see section related to HTO measurement).

In summary, amongst the six HCP samples, initially de-saturated at a fixed relative humidity using $\mathrm{KC}_{2} \mathrm{H}_{3} \mathrm{O}_{2}$ oversaturated saline solution, two of them were placed in air-tight containers with $\mathrm{LiCl}$ solution at $12.8 \mathrm{~mol} \mathrm{~kg}_{\text {water }}{ }^{-1}$. These two samples were kept for a period of 1 month to achieve the corresponding hydric equilibrium (from RHs equal to $23 \%$ to $29 \%$ ). The other samples were placed in desiccators with over-saturated saline solutions of $\mathrm{K}_{2} \mathrm{SO}_{4}$ or $\mathrm{KI}$ for the period of 5 months until mass stabilization was reached. Afterwards, for each relative humidity investigated, one sample was dismantled for petrophysical measurements and the other one was dedicated to the diffusion experiment (see Table 1).

For in-diffusion step, glass-made air-tight container was used to host both about $5 \mathrm{~g}$ of $\mathrm{LiCl}$ solution labelled with HTO $(\sim 10 \mathrm{kBq})$, continuously stirred to maintain the homogeneity of the system, and the suspended cement sample inside the chamber (Fig. 1b). In the case of the two diffusion experiments carried out at $69 \%$ and $98 \%$ of RH, the annulus of HCP samples was sealed with epoxy resin (Sikadur ${ }^{\circledR}$ ) to limit HTO diffusion to both sides. For the experiment at RH close to $29 \%$, as the diffusion rate was expected to be faster than at full saturation, by analogy with the diffusive behavior of dihydrogen into the same material [6], the annulus and one side of the sample were sealed. In this condition, as HTO diffusion should have occurred through whole of the sample thickness, diffusion time was expected to be long enough to prevent vapor exchange from being the limiting factor (see below). Moreover, a humidity/temperature probe was installed through the cover cap of the container (Hygroclip2, Rotronic, Switzerland) to check the stability of $\mathrm{RH} / \mathrm{T}^{\circ}$ values throughout the experimental time (Fig. 1b). For the three experiments, RH had shown a standard deviation less than $1.5 \%$ for a period of 300 days. Finally, each container was drilled from four sides and sealed with a septum. Using this septum very small aliquot of $\mathrm{LiCl}$ solution (less than $0.1 \mathrm{~g}$ ) was withdrawn using a needle and a syringe to follow the evolution of HTO activity in the saline solution. When HTO equilibrium was achieved, out-diffusion step was started by replacing $\mathrm{LiCl}$ solution initially labelled with HTO by HTO-free LiCl solution. Using the septum, samplings similar to indiffusion step were carried out to monitor HTO diffusing from HCP sample to the LiCl solution. 
In order to qualify the HTO exchange setup, two preliminary tests were performed with HTO alone $\mathrm{LiCl}$ solution labelled with HTO in air-tight container in order to check the presence of any potential leakage of HTO or possibility of some HTO adsorption on the walls of the setup. After a period of more than 1 month, the monitoring of the HTO activity revealed no significant evolution, indicating the absence of experimental artifacts. For the second test, two cups one filled with $\mathrm{LiCl}$ solution labelled with HTO and the other filled with HTO-free $\mathrm{LiCl}$ solution were placed into the setup. The objective here was to estimate the kinetics of HTO exchange from HTO-enriched solution to HTOfree solution, via vapor phase. This duplicated experiment showed that in less than three days HTO activity equilibrium was achieved between the two cups. This test thus, suggests that the vapor exchange would not be a limiting factor in diffusion experiments that lasts for more than 50 days each.

\subsection{Analytical issue}

${ }^{3} \mathrm{H}$ radio-isotope is a beta-emitter $\left(\mathrm{E}_{\max }=18.6 \mathrm{keV}\right)$. Classically, the HTO activity is determined using a liquid scintillation counting, e.g. Packard SL2700 liquid scintillation counter. However, in presence of highly-concentrated saline solutions or organic molecules like PEG, counting efficiency can be strongly impacted by quenching effects. Therefore, to optimize the counting efficiency, the withdrawn solution was significantly diluted in deionized water (i.e. $0.1 \mathrm{~g}$ of concentrated solution in $3.9 \mathrm{~g}$ of water). This dilution led to a maximum of $0.2 \mathrm{~mol} \mathrm{~kg}^{-1}$ of water for $\mathrm{LiCl}$ instead of 12.8 mol $\mathrm{kg}_{\text {water }}{ }^{-1}$, and $0.012 \mathrm{~g}$ of PEG per $\mathrm{g}$ of solution without PEG, instead of $0.95 \mathrm{~g}$ of PEG per $\mathrm{g}$ of solution without PEG. After this step, $16 \mathrm{ml}$ of liquid scintillation cocktail (Ultima GoldTM cocktail, UG, PerkinElmer, USA) was added to this solution in a 20-ml-polyethylene vial. This dilution ensured that $\mathrm{LiCl}$ and $\mathrm{PEG}$ concentrations in scintillation vials reached acceptable values limiting analytical artifacts. It is to be noted that this protocol was strictly applied in terms of withdrawn sample mass to limit bias related to some discrepancies between each sampling.

The counting efficiency was measured as a function of TSiE (transformed spectral index of the external standard) using synthetic solutions with known amounts of ${ }^{3} \mathrm{H}$ radio-activities and various amount of quencher. Background measurements were performed in a similar way using synthetic solution without radiotracers. Data were corrected for radioactive decay using the time of tracer addition as reference date. As half-life radioactive period of ${ }^{3} \mathrm{H}\left(\mathrm{T}_{1 / 2}=(12.312 \pm 0.025)\right.$ years $)$ is long enough as compared to the total experiment-time in this study, this correction is negligible.

\subsection{Treatment of experimental results}

The experimental results were analyzed by applying Fick's second law for one-dimensional transport for a porous medium:

$$
\frac{\partial C}{\partial t}=\frac{D_{e}}{\alpha} \frac{\partial^{2} C}{\partial x^{2}}=\frac{D_{e}}{\varepsilon_{a}+\rho_{d} R_{D}} \frac{\partial^{2} C}{\partial x^{2}}
$$

Where $C$ is the concentration or activity per volume unit in the solute phase ( $\mathrm{mol} \mathrm{m}^{-3}$ of pure water or $\mathrm{Bq} \mathrm{m}{ }^{-3}$ of pure water); $t$, the time (s); $D_{e}$, the effective diffusion coefficient $\left(\mathrm{m}^{2} \mathrm{~s}^{-1}\right) ; \varepsilon_{a}$, the diffusionaccessible porosity $\left(\mathrm{m}^{3} \mathrm{~m}^{-3}\right) ; \rho_{d}$, the bulk dry density $\left(\mathrm{kg} \mathrm{m}^{-3}\right) ; \alpha$ is the material capacity factor $(-)$; the distribution ratio, $R_{D}\left(1 \mathrm{~kg}^{-1}\right)$. 
If there is some interaction between HTO and solid, $R_{D}$, can be calculated from the relationship, $R_{D}=\left(\alpha-\varepsilon_{a}\right) / \rho_{d}$, assuming that the diffusion-accessible porosity for HTO was identical to the volumetric moisture content, i.e. $\varepsilon_{a}=\theta=\phi$. $S_{w}$.

Thus, depending on the type of diffusion experiments, different boundary and initial conditions needs to be considered.

For a through-diffusion system, boundary and initial conditions are as follows:

$$
\begin{array}{ll}
C(x, t)=0, & t=0 \\
C(x, t)=C_{0}, & x=0, t>0 \\
C(x, t)=0, & x=L, t>0
\end{array}
$$

Where $L$ is the sample thickness $(\mathrm{m})$ and $C_{0}$ is the concentration of the tracer in the upstream reservoir ( $\mathrm{mol} \mathrm{m}^{-3}$ of pure water or Bq $\mathrm{m}^{-3}$ of pure water). Fully analytical solution of equation (4) is given by equation (8) in reference with equation (4.24a) of Crank [27]:

$$
A_{d i f}=S . L . C_{0} \cdot\left[\frac{D_{e} \cdot t}{L^{2}}-\frac{\alpha}{6}-\frac{2 \cdot \alpha}{\pi^{2}} \sum_{n=1}^{\infty} \frac{(-1)^{n}}{n^{2}} \cdot \exp \left\{-\frac{D_{e} \cdot n^{2} \cdot \pi^{2} \cdot t}{L^{2} \cdot \alpha}\right\}\right]
$$

Equation (8) gives the cumulative amount of tracer, $A_{d i f}$ (mole or $\mathrm{Bq}$ ) in the downstream reservoir when $x=L$. $S$ is the surface of the sample $\left(\mathrm{m}^{2}\right)$. Here, results were analyzed by a least-square fitting of the model to the results of the cumulative activity in the downstream reservoir, using equation (8).

For in-diffusion experiments, if we assume that the transfer in vapor phase is so fast that only diffusion in liquid phases has to be considered (see above), the initial and the boundary conditions are:

$$
\begin{array}{ll}
C(x, t)=0, & L \geq x>0, t=0 \\
C(x, t)=C_{0}, & x=0, t=0 \\
\frac{\partial C}{\partial x}=0, & x=L, t \geq 0
\end{array}
$$

Where for experiments at $98 \%$ and $69 \%$ of relative humidity, $L$ is half thickness of sample (diffusion on both sides), while for experiment at $29 \%$ of RH, $L$ is the whole thickness (diffusion on only one side).

For out-diffusion experiments, only changed the initial conditions:

$$
\begin{aligned}
& C(x, t)=C_{e q}, \quad L \geq x>0, t=0 \\
& C(x, t)=0, \quad x=0, t=0
\end{aligned}
$$

Where $C_{e q}$ is the equilibrated concentration of the tracer in cement paste at the end of in-diffusion

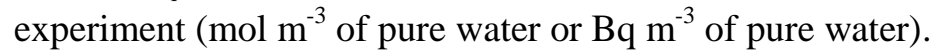

Under such conditions, following analytical solutions given by Crank [27] (equations 4.45 and 4.47) can be considered to express the concentration evolution in single reservoir for in- and outdiffusion, respectively: 
Where $\beta$ is equal to $\frac{V_{\text {test_water }}}{V_{\text {sample }} \alpha}$ with $V_{\text {test_water, }}$, the volume of pure water in solution (L) and $q_{n}$ s are the non-zero positive roots of $\tan \left(q_{n}\right)=-\beta q_{n}$.

\section{Results and discussion}

\subsection{Petrophysical data}

Fig. 2 shows the evolution as a function of imposed relative humidity of each degree of saturation measured on hardened cement pastes (HCP). The series dedicated to through-diffusion carried out under osmosis exhibits a good consistency between HCPs that have undergone re-saturation at relative humidity (RH) fixed by oversaturated saline solutions. For this "osmotic" sample, the degree of saturation is equal to $(0.85 \pm 0.01)$. Moreover, the impact of relative humidity values used for the initial de-saturation is clearly revealed by two series of HCP samples that have undergone RH equal to $69 \%$, with a difference in their degree of saturation close to 0.25 . This phenomenon is well documented in literature, especially by Baroghel-Bouny [28]. This work has well explained hysteresis behavior by a different pore filling when desaturating (blue dot series in Fig. 2) and re-saturating (red dot series in Fig. 2), related to the degree of constriction of the pores, the "inkbottle effect", as well as the possible different liquid-vapor interface shapes (curvatures). Finally, samples dedicated to in- and out-diffusion experiments carried out under RH fixed by under-saturated saline solutions have saturation degree $\left(S_{w}\right)$ values equal to $(0.23 \pm 0.01),(0.42 \pm 0.01)$ and $(0.87 \pm 0.01)$.

\subsection{HTO diffusion data obtained under osmotic suction}

Fig. 3 shows the cumulative activity of HTO for two through-diffusion experiments $\left(S_{w}=0.85 \&\right.$ $\left.S_{w}=1.00\right)$. The cumulated activity of HTO is lowered when the sample is partially water-saturated. An overview of the values of estimated diffusive parameters for HTO is given in Table 2, showing a decrease of $D_{e}$ by a factor of almost 2 from $S_{w}=1.00$ to $S_{w}=0.85$. Moreover, for unsaturated sample, experimental data were only reproduced using a non-null value for $R_{D}$, contrary to the fully-saturated case.

\subsection{HTO diffusion data using vapor exchange approach}

The results obtained from in- and out-diffusion experiments carried out on three partially-saturated HCP samples were reported in Fig. 4. Uses of $\mathrm{Eq}(14)$ and $\mathrm{Eq}(15)$ with diffusive parameters given in Table 2 allowed the reproduction of the experimental data by associated modelling curves which are also reported in Fig. 4. For the samples at $S_{w}=0.87$ and $S_{w}=0.42$, regular evolution of activity in single reservoir can be noticed until the plateaus are reached. This state corresponds to equilibrium achievement between activity in solution and HCP pore-water solution. However, for the most desaturated sample, 190 days of in-diffusion experiment were not enough to reach equilibrium. 
Therefore, such unexpected behavior led us to switch to the out-diffusion step, due to too small volume of test solution remaining at the end of in-diffusion step. This means that data interpretation was less constrained, due to the absence of plateau. As a result of this the $R_{D}$ value was not properly estimated.

A comparison of the corresponding diffusive parameters used for three degrees of saturation showed that the more de-saturated the HCP samples, the lower the effective diffusion coefficient values, with a reduction by a factor of 5 , from $S_{w}=0.87$ to $S_{w}=0.23$ (Table 2). Moreover, while at $S_{w}$ $=0.87$, the $R_{D}$ value estimated from the out-diffusion experiment was very close to the one estimated from the in-diffusion experiment, below $S_{w}=0.42$ the $R_{D}$ values estimated from the out-diffusion experiments were lower than ones estimated from the in-diffusion experiments. This suggests occurrence of some irreversible or lower-kinetics phenomena capable of limiting the diffusion of HTO out of samples when degrees of saturation are low enough. Takata et al. [13], Furuichi et al. [14] and Kim et al. [17] explained that exchange reactions between structural water in HCP and HTO could lead to some irreversible HTO uptake in HCP. However, these authors did not specify any saturation degree under which these phenomena could take place.

\subsection{Comparison with dihydrogen diffusion}

All the values of effective diffusion coefficient, $D_{e}$, obtained from the two types of diffusion experiments were reported in Fig. 5 as a function of $\mathrm{HCP}$ saturation degree. These two techniques led to $D_{e}$ values in good agreement when obtained on HCP samples at near degrees of saturation, i.e. $S_{w}$ $=0.85$ and $S_{w}=0.87$, demonstrating their reliability. Comparison of these results with $D_{e}$ values for dihydrogen obtained onto CEM V/A HCP samples with a near water/cement ratio (i.e. 0.45) by Sercombes et al. [6] clearly indicates a distinct behavior when degrees of saturation decrease. While the diffusion rate for dihydrogen increases by more than three orders of magnitude from $S_{w}$ close to saturation to $S_{w}$ lower than 0.8 , the diffusion rate for HTO is reduced by one order of magnitude as $S_{w}$ decreases from 1 to 0.23 . This discrepancy can be explained by portioning phenomena taking place during the diffusion process. When dehydrating, the contribution of water vapor phase to diffusion would remain minor compared to the diffusion in liquid phase for HTO because of the partitioning of water $\left(\mathrm{C}_{\text {liquid }} / \mathrm{C}_{\text {gas }} \approx 1000\right.$ for HTO at $\left.25^{\circ} \mathrm{C}[29]\right)$, contrary to dihydrogen that diffuses mainly under gaseous form. Finally, it is noteworthy that tritiated water exhibits an intermediate diffusive behavior between dihydrogen, a gas with lower interaction with the liquid phase and ionic species that are forced to diffuse in liquid phase, such as lithium studied by Dridi and Lacour [4] showing a sharp decrease of its diffusivity when dehydrating.

\section{Conclusion}

The diffusion of tritiated water through unsaturated cement-based materials was studied using two complementary techniques. Both of these techniques enabled us to investigate degree of saturation $\left(S_{w}\right)$ from 0.23 to full-saturation. Although the first technique was initially developed for studying diffusion through clay-rich materials that are partially saturated using osmosis process, our present work demonstrates that it can be successfully adapted to cement-based materials. At the highest suction of $9 \mathrm{MPa}, \mathrm{HCP}$ sample reached a $S_{w}$ of 0.85 . This value is in very good accordance with $S_{w}$ of other samples that have undergone near suctions by means of the most classical over-saturated saline method. A clear decrease of diffusion rate (by a factor of two) for HTO was evidenced between the fully-saturated HCP sample and one at $S_{w}=0.85$. The second technique enabled diffusion experiments to be performed in humidity chambers controlled by under-saturated saline solutions ( $\mathrm{LiCl})$. The injected $\mathrm{HTO}$ in the $\mathrm{LiCl}$ solution diffused in the studied material under its gas form. In this form it 
further dissociated between gaseous and liquid forms when diffusing. Preliminary tests have confirmed that in our setup, HTO is not absorbed by the surfaces. Moreover, HTO vapor exchange was fast enough ( $<3$ days), thus not standing as a limiting factor for in-diffusion experiments that lasted for a period more than 80 days each. Using this principle, in- and out-diffusion experiments for HTO were carried out to quantify its effective diffusion coefficient and retention properties into HCP samples at $S_{w}=0.87,0.42$ and 0.23 . For similar saturation degrees, a good agreement for measured diffusive parameters was obtained between the two techniques using either osmosis or saline solution to fix suction. Moreover, comparison of data acquired from in- and out-diffusion experiments showed a non-negligible HTO amount trapped into HCP and unable to diffuse out of the sample when dehydrating suggesting some irreversible HTO uptake in the HCP matrices. Combining the results acquired from both of these techniques has revealed a decrease of the HTO effective diffusion coefficient by one order of magnitude when dehydrating from full-saturation to $S_{w}=0.23$. These results suggest that tritiated water would behave in an intermediate manner between gases, e.g. $\mathrm{H}_{2}$ or HT, and ionic species when diffused through unsaturated HCP pastes.

Such a study using these two complementary techniques could be therefore considered as a milestone for future diffusion experiments where investigations could be from now performed under a large range of saturation degree. As a promising improvement, this will enable us to conduct HTO diffusion measurements through other cement-based materials like mortars and even concretes, also extensively used in nuclear field but also to study the diffusive behavior of other species of interest occurring in gas and liquid phases such as carbon-14 or iodine-129 for the radionuclides ones and $\mathrm{HCN}$ or $\mathrm{Hg}$ for the toxic ones.

\section{Acknowledgements}

This work received financial support from Andra. 


\section{References}

[1] C. Jantzen, A. Johnson, D. Read, J. Stegemann, Cements in waste management, Adv. Cem. Res. 22 (2010) 225-231.

[2] Andra, 2005. Dossier 2005 argile - Tome - Evolution phénoménologique du stockage géologique; Rapport Andra ${ }^{\circ}$ C.RP.ADS.04.0025, France; http://www.andra.fr/download/siteprincipal/document/editions/182.pdf, 2005 (accessed 27.06.17).

[3] O. Cuisinier, F. Masrouri, Influence de sollicitations hydriques et mécaniques complexes sur le comportement d'un sol gonflant compacté, Can. Geotech. J. 42 (2005) 731-741.

[4] W. Dridi, J.L. Lacour, Experimental investigation of solute transport in unsaturated cement pastes, Cem. Concr. Res. 63 (2014) 46-53.

[5] S. Numata, H. Amano, K Minami, Diffusion of tritiated water in cement materials, J. Nucl. Mat. 171 (1990) 373-380.

[6] J. Sercombes, R. Vidal, C. Gallé, F. Adenot, Experimental study of gas diffusion in cement paste, Cem. Concr. Res. 37 (2007) 579-588.

[7] S. Savoye, P. Page, C. Puente, C. Imbert, D. Coelho, A new experimental approach for studying diffusion through an intact and unsaturated medium: A case study with Callovo-Oxfordian argillite, Environ. Sci. Technol. 44 (2010) 3698-3704.

[8] S. Savoye, C. Beaucaire, A. Fayette, M. Herbette, D. Coelho, Mobility of cesium through the Callovo-Oxfordian claystones under partially saturated conditions. Environ. Sci. Technol. 46 (2012) 2633-2641.

[9] S. Savoye, C. Imbert, A. Fayette, D. Coelho, Experimental study on diffusion of tritiated water and anions under variable water-saturation and clay mineral content: comparison with the Callovo-Oxfordian claystones, Geol. Soc., London, Special Publications 400 (2014) 579-588.

[10] T. Melkior, S. Yahiaoui, D. Thoby, S. Motellier, V. Barthes, Diffusion coefficients of alkaline cations in Bure mudrock, Phys. Chem. Earth 32 (2007) 453-462.

[11] S. Savoye, C. Beaucaire, B. Grenut, A. Fayette, Impact of the solution ionic strength on strontium diffusion through the Callovo-Oxfordian clayrocks: An experimental and modeling study, Appl. Geochem. 61 (2015) 41-52.

[12] B. Larbi, W Dridi, P. Dangla, P. Le Bescop, Link between microstructure and tritiated water diffusivity in mortars: Impact of aggregates, Cem. Concr. Res. 82 (2016) 92-99.

[13] H. Takata, T. Motoshima, S. Satake, M. Nishikawa, Study of Tritium Behavior in Cement Paste, Fusion Sci. Technol. 48 (2005) 589-592.

[14] K. Furuichi, H. Takata, K. Katayama, T. Takeishi, M. Nishikawa, T. Hayashi, K. Kobayashi, H. Namba, Evaluation of tritium behavior in concrete, J. Nucl. Mat. 367-370 (2007) 1243-1247.

[15] A. Gudelis, T. Nedveckaite, N. Prokopciuk, V. Filistovic, V. Remeikis, S. Motiejunas, Assessment of radionuclide migration and radiological human exposure at the closed near-surface radioactive waste repository, Nukleonika 55 (2010) 251-259.

[16] J.R. Twining, C.E. Hughes, J.J. Harrison, S. Hankin, J. Crawford, M. Johansen, L. Dyer, Biotic, temporal and spatial variability of tritium concentrations in transpirate samples collected in the vicinity of a near-surface low-level nuclear waste disposal site and nearby research reactor, J. Environ. Radio. 102 (2011) 551-558.

[17] D. Kim, I.W. Croudace, P.E. Warwick, The requirement for proper storage of nuclear and related decommissioning samples to safeguard accuracy of tritium data. J. Hazard. Mat. 213- 214 (2012) 292- 298.

[18] A.P. Rübel, C. Sonntag, J. Lippmann, F.J. Pearson, A. Gautschi, Solute transport in formations of very low permeability: profiles of stable isotope and dissolved gas contents of pore-water in the Opalinus Clay, Mont Terri, Switzerland, Geochim. Cosmochim. Acta 66 (2002) 1311-1321

[19] S. Savoye, J.L. Michelot, C. Witterbroodt, M.V. Altinier, Contribution of the diffusive exchange method to the characterization of pore water in the consolidated argillaceous rocks, J. Contam. Hydrol. 86 (2006) 87-104.

[20] [20] M.V. Altinier, S. Savoye, J.L. Michelot, C. Beaucaire, M. Massault, D. Tessier, H.N. Waber, The isotopic composition of argillaceous-rocks pore water: an intercomparison study on the Tournemire argillite (France), Phys. Chem. Earth, 32 (2007) 209-218. 
[21]D. Kitic, D.C Pereira Jardim, G.J. Favetto, S.L. Resnik, J. Chirife, Theoretical predictions of the water activity of standard saturated salt solutions at various temperatures, J. Food Sci. 51 (1986) 1037-1041.

[22] J.F. Young, Humidity control in the laboratory using salt solutions - a review. J. Appl. Chem. 17 (1967) 241-245.

[23] K.D. Kamburova, P.P Kirilov, P.P., Solubility and Critical Relative Humidity of the System (KH2PO4 + K2HPO4 + H2O) at 298.15 K., J. Chem. Eng. Data 55 (2010) 2225-2228.

[24] W. Chen, J. Liu, F. Brue, F., Skoczylas, C.A. Davy, X. Bourbon, J. Talandier, Water retention and gas relative permeability of two industrial concretes, Cem. Concr. Res. 42 (2012) 1001-1013.

[25] P. Delage, M.D. Howat, Y.J. Cui, The relationship between suction and swelling properties in a heavily compacted unsaturated clay, Engin. Geol. 50 (1998) 31-48.

[26] A. Wexler, S. Hasegawa, Relative humidity-temperature relationships of some saturated salt solutions in temperature range $0{ }^{\circ} \mathrm{C}$ to $50{ }^{\circ} \mathrm{C}$, J. Res. Natl. Bur. Stand. 53 (1954) 19-26.

[27] J. Crank, The mathematics of diffusion, second ed., Oxford Science Publication, New York, 1975.

[28] V. Baroghel-Bouny, Water vapour sorption experiments on hardened cementitious materials: part I. Essential tool for analysis of hygral behaviour and its relation to pore structure, Cem. Concr. Res. 37 (2007) 414-437

[29] D.E. Smiles, W.R. Garner, R.K. Schulz, Diffusion of tritium in arid disposal sites, Water Resour. Res 31 (1995), 1483-1488. 
Figure captions

Fig. 1. (a) Cross-section sketch of the large sample holder used in the through-diffusion cell under osmosis. (b) Cross-section sketch of the setup used for in- and out-diffusion experiments. PEEK means polyetheretherketone.

Fig. 2. Saturation degree of saturation determined on hardened cement pastes (HCP) having undergone either osmotic method or saline solution method as a function of the equivalent relative humidity. Y-axis error bars are calculated from Gauss' propagation equation and X-axis error bars correspond to the uncertainty associated to the estimation of the relative humidity.

Fig. 3. Total diffused activity at the two values of saturation degree for HTO. The solid curves were calculated using the analytical solution $\mathrm{Eq}(8)$ with parameters specified in Table 2.

Fig. 4. (Left) Evolution as a function of time, of the normalized activity in the single reservoir during in-diffusion experiment; (Right) Evolution as a function of time, of the total activity in the single reservoir during out-diffusion experiment. The solid curves were calculated using the analytical solutions $\mathrm{Eq}(14)$ and $\mathrm{Eq}(15)$ with the parameters specified in Table 2.

Fig. 5. Values of the effective diffusion coefficient values $\left(D_{e}\right)$ for HTO determined on hardened cement pastes (HCP) as a function of their saturation degree. Comparison with the effective diffusion coefficient values for dihydrogen obtained by Sercombes et al. [6] through the same type of cementbased materials. 
Table 1

Summary of the samples and the type of experiments performed in this study.

\begin{tabular}{|c|c|c|c|c|c|}
\hline $\begin{array}{l}\text { Diffusion } \\
\text { technique }\end{array}$ & $\begin{array}{l}\text { Suction } \\
\text { method }\end{array}$ & $\begin{array}{c}\text { Sample } \\
\text { thickness } \\
(\mathrm{mm})\end{array}$ & $\begin{array}{l}\text { Sample diameter } \\
(\mathrm{mm})\end{array}$ & $\begin{array}{l}\text { Concentration of } \\
\text { PEG or } \mathrm{LiCl} \text { in } \\
\text { solution }\end{array}$ & $\begin{array}{c}\text { Equivalent } \\
\text { relative } \\
\text { humidity }(\%)\end{array}$ \\
\hline $\begin{array}{l}\text { Through- } \\
\text { diffusion }\end{array}$ & Osmosis & 0.9 & 36 & $0 \mathrm{~g}$ of $\mathrm{PEG} / \mathrm{g}_{\mathrm{water}}$ & 100 \\
\hline $\begin{array}{l}\text { Though- } \\
\text { diffusion }\end{array}$ & Osmosis & 1.3 & 36 & $\begin{array}{c}0.95 \mathrm{~g} \text { of } \\
\mathrm{PEG} / \mathrm{g}_{\text {water }}\end{array}$ & 93 \\
\hline $\begin{array}{l}\text { In- and out- } \\
\text { diffusion }\end{array}$ & $\begin{array}{l}\text { Saline } \\
\text { solution }\end{array}$ & 2.6 & 49 & $\begin{array}{c}1.2 \mathrm{~mol} \text { of } \mathrm{LiCl} \\
\mathrm{kg}_{\text {water }}^{-1}\end{array}$ & 98 \\
\hline $\begin{array}{l}\text { In- and out- } \\
\text { diffusion }\end{array}$ & $\begin{array}{l}\text { Saline } \\
\text { solution }\end{array}$ & 2.5 & 49 & $\begin{array}{c}5.5 \mathrm{~mol} \text { of } \mathrm{LiCl} \\
\mathrm{kg}_{\text {water }}^{-1}\end{array}$ & 69 \\
\hline $\begin{array}{l}\text { In- and out- } \\
\text { diffusion }\end{array}$ & $\begin{array}{l}\text { Saline } \\
\text { solution }\end{array}$ & 2.55 & 49 & $\begin{array}{c}12.8 \mathrm{~mol} \text { of } \mathrm{LiCl} \\
\mathrm{kg}_{\text {water }}{ }^{-1}\end{array}$ & 29 \\
\hline
\end{tabular}




\section{Table 2}

Values of effective diffusion coefficient $\left(D_{e}\right)$, material capacity factor $(\alpha)$ and distribution ratio $\left(R_{D}\right)$. Values between brackets indicate the uncertainty ranges.

\begin{tabular}{|c|c|c|c|c|c|c|}
\hline $\begin{array}{l}\text { Diffusion } \\
\text { technique }\end{array}$ & $\begin{array}{l}\text { Suction } \\
\text { method }\end{array}$ & $\begin{array}{l}\text { Saturation } \\
\text { degree, } \\
(-)\end{array}$ & $\begin{array}{c}\text { Volumetric water } \\
\text { content, } \theta \text {, } \\
(-)\end{array}$ & $\begin{array}{c}D_{e} \times 10^{-13} \\
\left(\mathrm{~m}^{2} \mathrm{~s}^{-1}\right)\end{array}$ & $\begin{array}{c}\text { Material } \\
\text { capacity factor, } \\
\alpha \\
(-)\end{array}$ & $\begin{array}{c}R_{D} \\
\left(1 \mathrm{~kg}^{-1}\right)\end{array}$ \\
\hline $\begin{array}{l}\text { Through- } \\
\text { diffusion }\end{array}$ & Osmosis & 1 & 0.33 & $\begin{array}{c}7.5 \\
(6.5-9.5)\end{array}$ & 0.33 & 0 \\
\hline $\begin{array}{l}\text { Though- } \\
\text { diffusion }\end{array}$ & Osmosis & 0.85 & 0.27 & $\begin{array}{c}4.0 \\
(4.0-4.7)\end{array}$ & $\begin{array}{c}0.65 \\
(0.54-0.81)\end{array}$ & $\begin{array}{c}0.22 \\
(0.15-0.31)\end{array}$ \\
\hline In-diffusion & $\begin{array}{l}\text { Saline } \\
\text { solution }\end{array}$ & 0.87 & 0.29 & $\begin{array}{c}5.0 \\
(4.0-7.0)\end{array}$ & $\begin{array}{c}1.0 \\
(0.9-1.25)\end{array}$ & $\begin{array}{c}0.4 \\
(0.35-0.55)\end{array}$ \\
\hline Out-diffusion & $\begin{array}{l}\text { Saline } \\
\text { solution }\end{array}$ & 0.87 & 0.29 & $\begin{array}{c}5.0 \\
(4.5-6.0)\end{array}$ & $\begin{array}{c}0.9 \\
(0.8-1.1)\end{array}$ & $\begin{array}{c}0.36 \\
(0.3-0.45)\end{array}$ \\
\hline In-diffusion & $\begin{array}{l}\text { Saline } \\
\text { solution }\end{array}$ & 0.42 & 0.14 & $\begin{array}{c}1.4 \\
(1.0-1.6)\end{array}$ & $\begin{array}{c}1.05 \\
(0.9-1.4)\end{array}$ & $\begin{array}{c}0.6 \\
(0.5-0.8)\end{array}$ \\
\hline Out-diffusion & $\begin{array}{l}\text { Saline } \\
\text { solution }\end{array}$ & 0.42 & 0.14 & $\begin{array}{c}1.3 \\
(1.1-1.4)\end{array}$ & $\begin{array}{c}0.25 \\
(0.20-0.29)\end{array}$ & $\begin{array}{c}0.14 \\
(0.115-0.165)\end{array}$ \\
\hline In-diffusion & $\begin{array}{c}\text { Saline } \\
\text { solution }\end{array}$ & 0.23 & 0.08 & $\begin{array}{c}0.8 \\
(0.7-0.9)\end{array}$ & $\begin{array}{c}0.71 \\
(0.42-1.3)\end{array}$ & $\begin{array}{c}0.36 \\
(0.2-0.7)\end{array}$ \\
\hline Out-diffusion & $\begin{array}{c}\text { Saline } \\
\text { solution }\end{array}$ & 0.23 & 0.08 & $\begin{array}{c}0.9 \\
(0.8-1.0)\end{array}$ & $\begin{array}{c}0.25 \\
(0.24-0.29)\end{array}$ & $\begin{array}{c}0.1 \\
(0.09-0.12)\end{array}$ \\
\hline
\end{tabular}


(a)
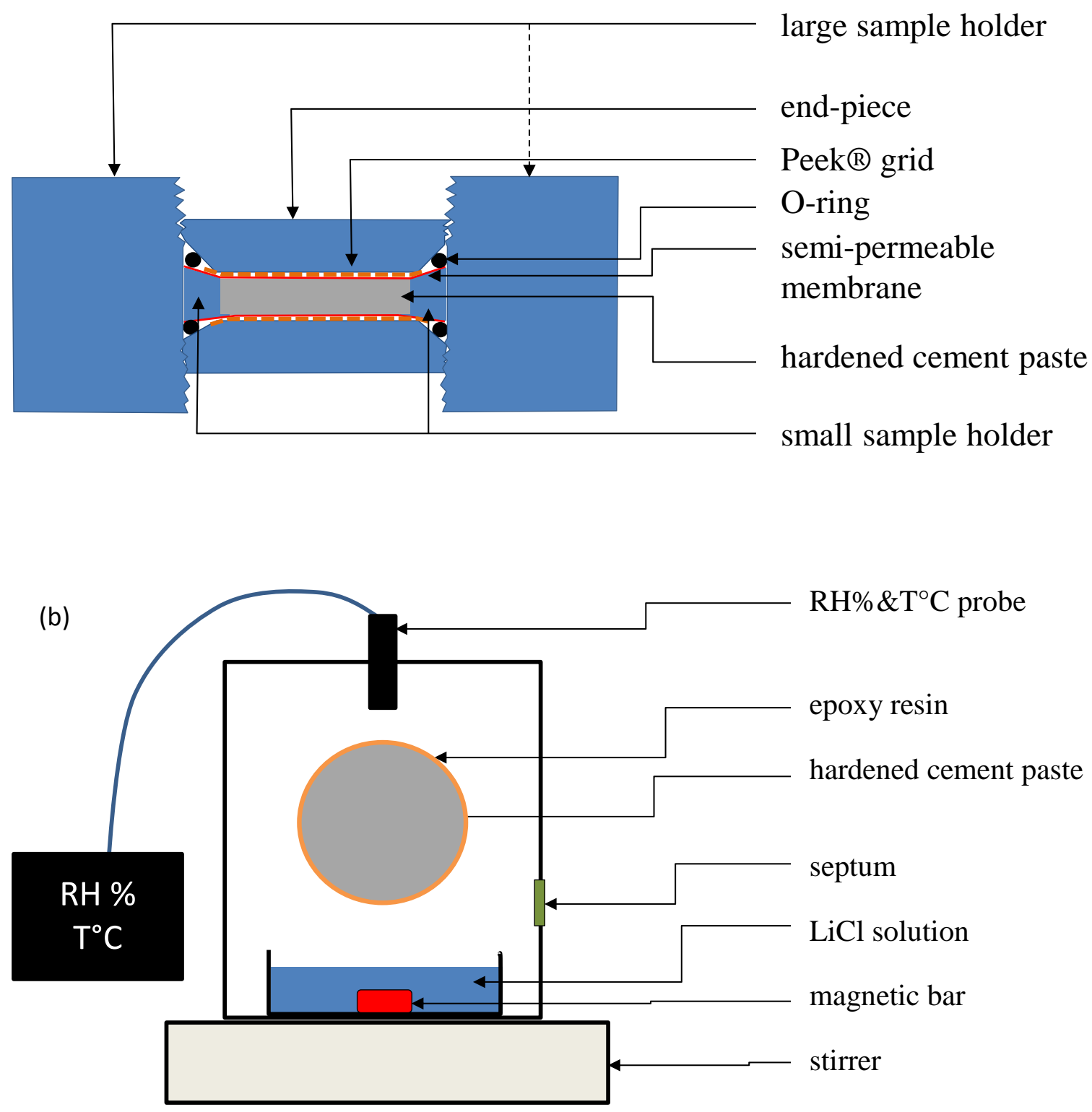

Fig. 1 


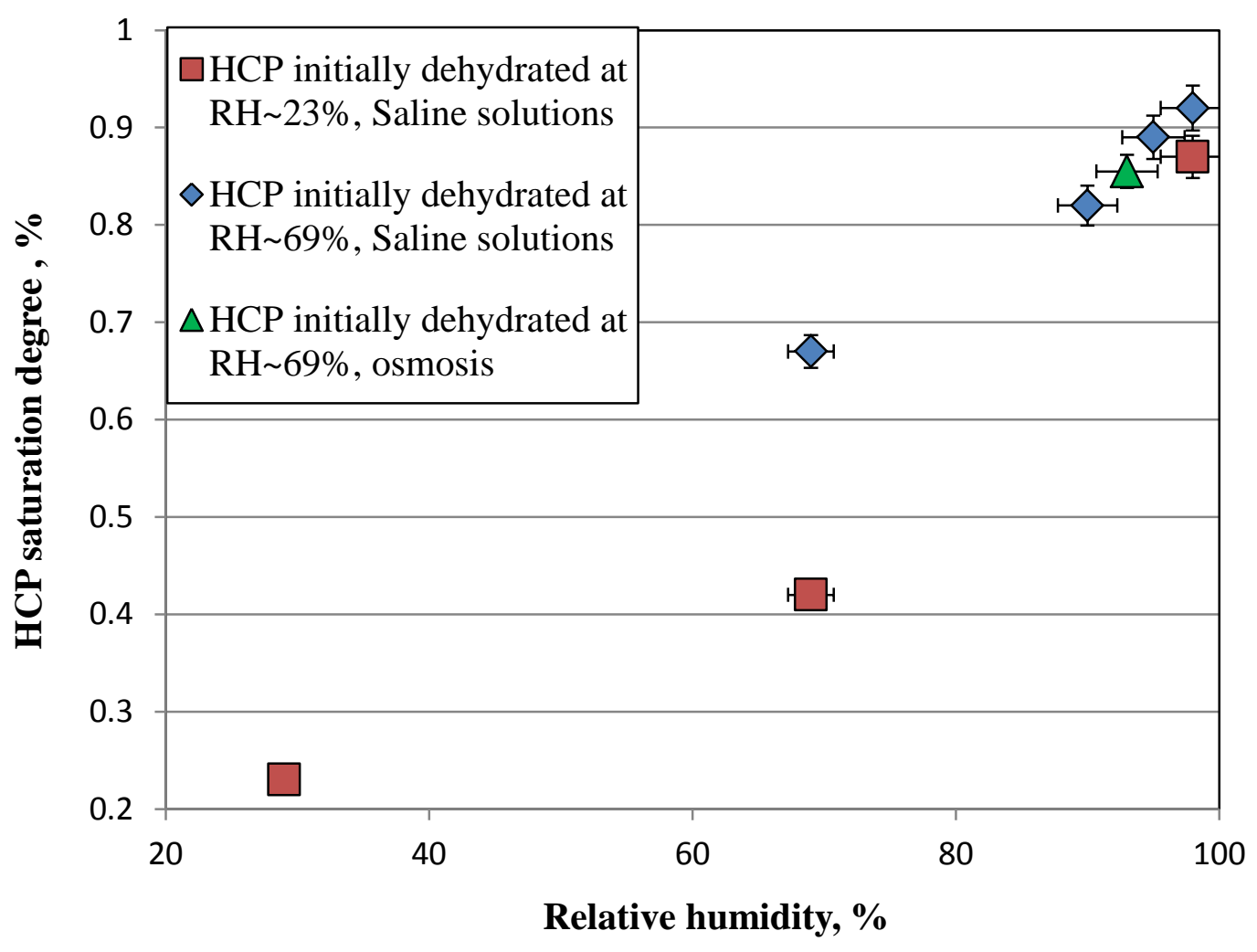

Fig. 2. 


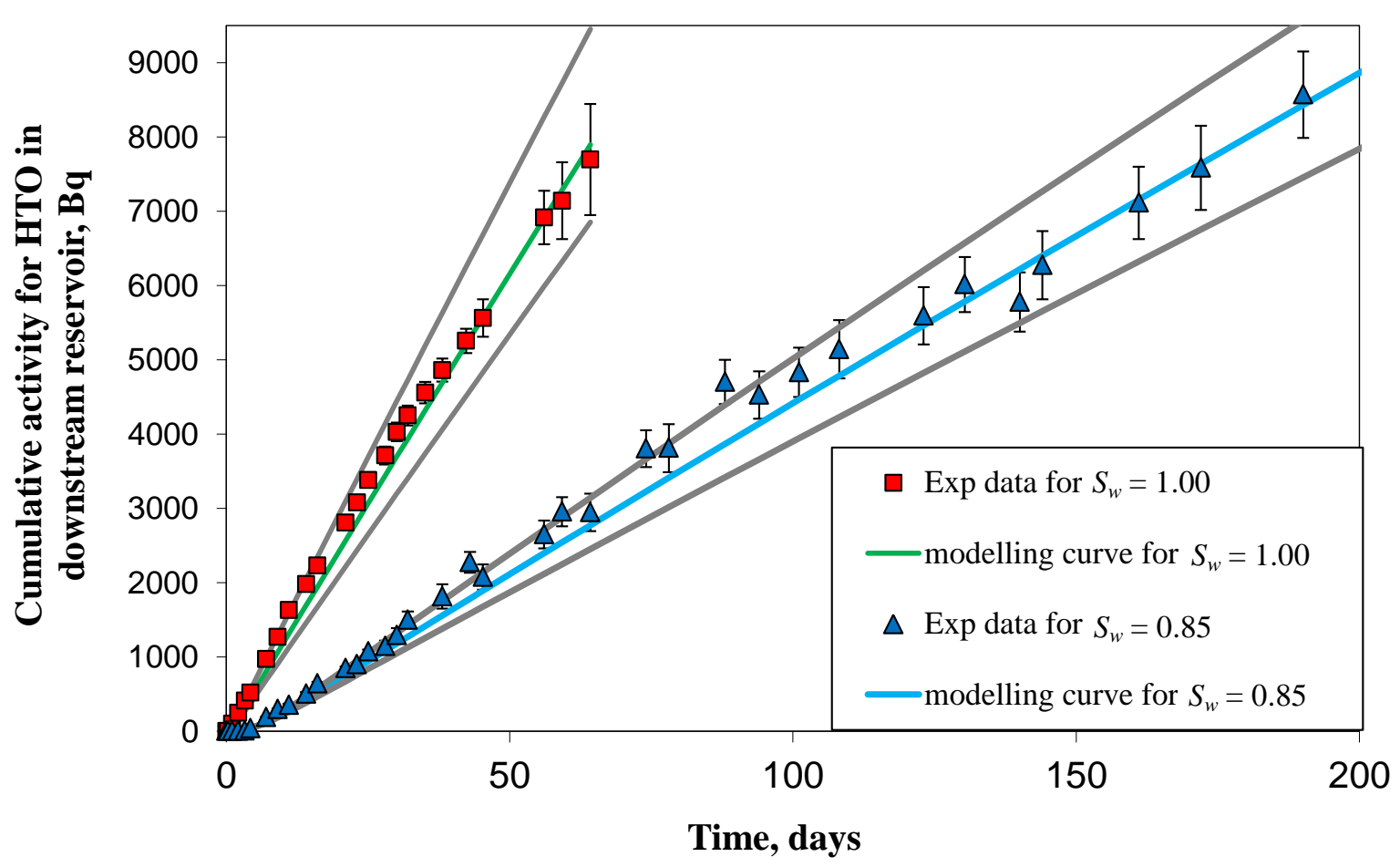

Fig. 3. 

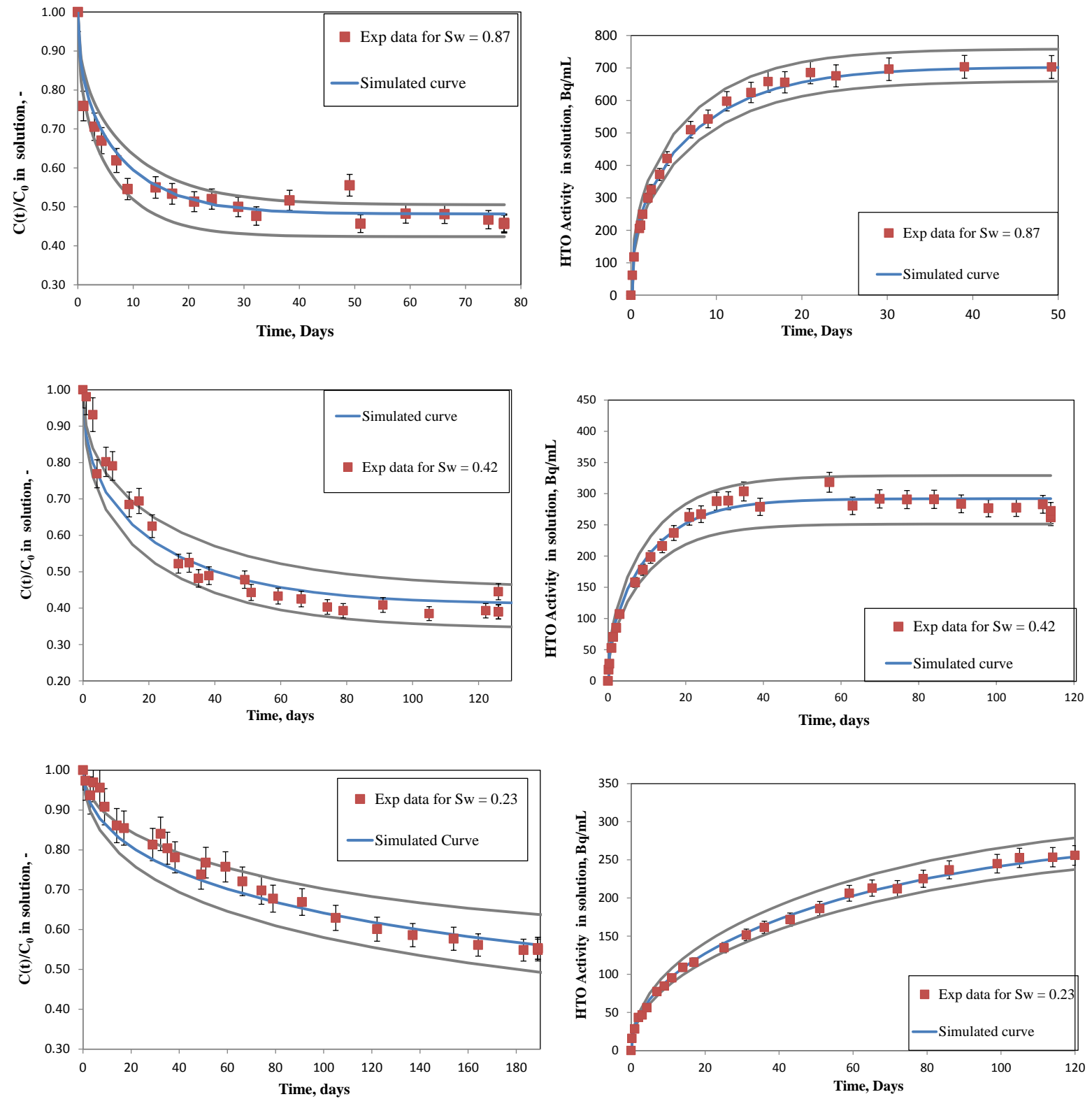

Fig. 4. 


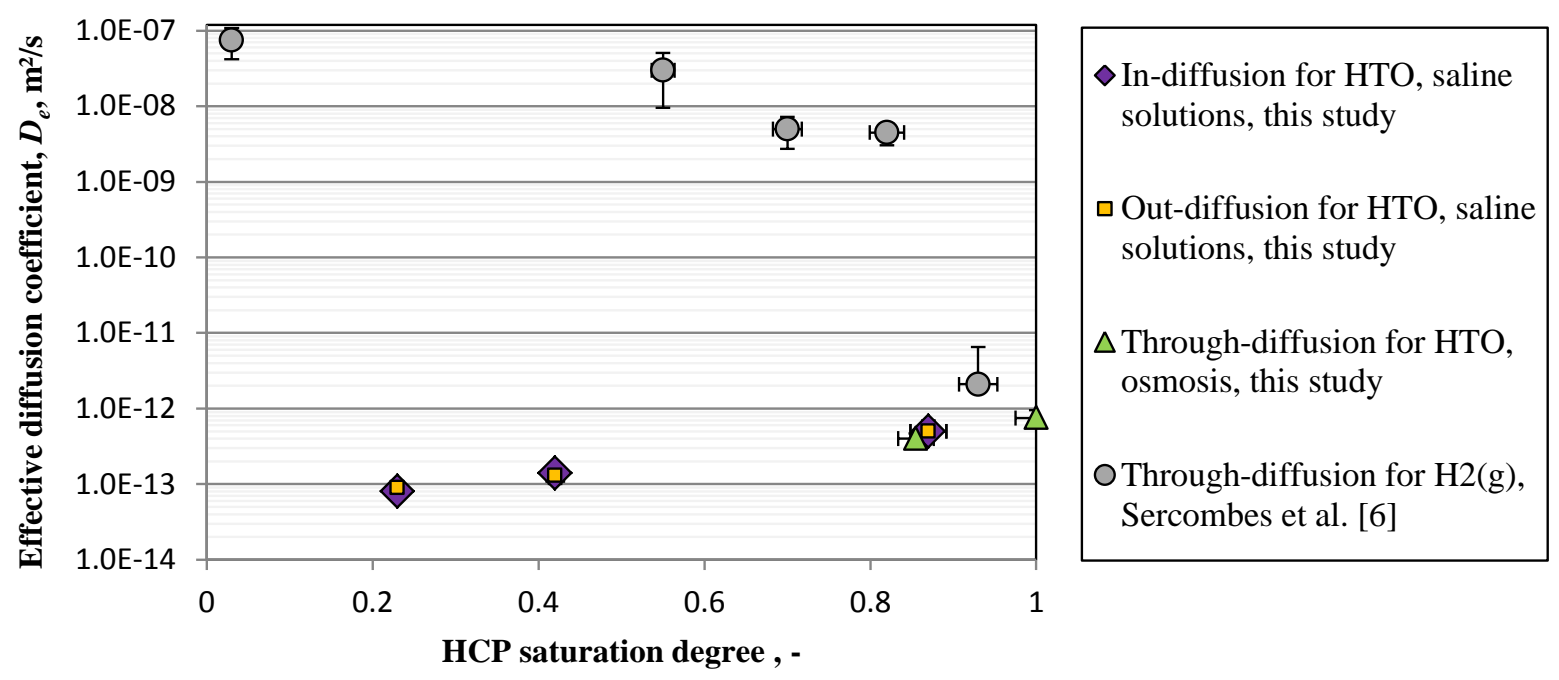

Fig. 5. 